\title{
Religious Mythology: The Problem of Aberration of Infernal Characters in Japanese "Anime"
}

\author{
Rafael A. Burkhanova, Evgenia V. Ivanova ${ }^{b^{*}}$ \\ and Anna D. Kolpakovab \\ ${ }^{a}$ Surgut State University \\ 1 Lenin, Surgut, Khanty-Mansiysk Autonomous okrug, \\ 628403, Russia \\ ${ }^{b}$ Ural Federal University \\ named after the First President of Russia B. N. Yeltsin \\ 51 Lenina, Ekaterinburg, 620083, Russia
}

Received 06.11.2018, received in revised form 30.04.2019, accepted 08.05.2019

\begin{abstract}
The article represents the study, devoted to the peculiarities of the modern infernal religious mythology manifestation in the space of mass media. The authors' interest is focused on the analysis of the locus of religious mythology from through the aberration of Western culture characters on the Japanese ones. Thereby the narrative scope of the author's concept of "religious mythology" is expanded. The interaction of mass culture and religion within the framework of a single study is increasingly common, however, the syntax of Shintoism and anime is a rare, although, relevant topic. In this article, the authors set the task of examining and analysing the influence of Shintoism, Christianity, Buddhism and American culture on the interpretation of infernal cultural heroes (characters) in the media discourse of Japanese animation developed during the creation of animated films and TV series.
\end{abstract}

Keywords: myth, religion, religious mythology, mass culture, cultural hero, infernal cultural character, Japanese anime, Japanese culture.

Research area: philosophy.

Citation: Burkhanov, R.A., Ivanova, E.V., Kolpakova, A.D. (2019). Religious mythology: the problem of aberration of infernal characters in Japanese "Anime". J. Sib. Fed. Univ. Humanit. soc. sci., 12(5), 752-763. DOI: 10.17516/1997-1370-0420.

\section{Introduction}

Japan is a country with a culture for years shielded from the influence of some "external" factors that, in turn, has made it unique. In addition to this historical fact,

(C) Siberian Federal University. All rights reserved

* Corresponding author E-mail address: ieviev@mail.ru

This work is licensed under a Creative Commons Attribution-NonCommercial 4.0 International License (CC BY-NC 4.0). 
it is interesting to mark the leading role of ritual component in the life of Japanese people. Today, under intercultural communications and searches for new types of spiritual practices, there is a growing interest in various Eastern religious cultures and practices, including the Japanese culture, which combines elements of traditional Shinto beliefs as well as the ones translated through the mass media.

Since the advent of animated films in Japan, regarded as a special art, significant changes peculiar to the mass culture of this country have occurred. This owes to a "mascot" and new types of personality used by the authors of "anime" and perceived by the viewer as permanent formulas accepted by the society, as well as to the inversion of certain ethical norms and values of Western and American cultures, borrowed from cross-cultural communications by Eastern (Japanese) mentality. More importantly to point out the speed of development and expansion of "anime", resulted in the $20^{\text {th }}$ century in an animation boom, and that now is shifting into the cult of animated characters, having various forms of expression: festivals, where people transform into their favourite characters, images of heroes in everyday items, posters or figures. Looking to the modern Japan, it is worth noting that from the Western culture the Shintoists have adopted a multidimensional set of not only social, but also religious stereotypes, expressed in mythogenesis updating and "virtual" reality effect created in the real material world. The effect of "being renewed" from the rituals is also being comprehended differently among the modern Japanese. From understanding it as a new stage of life in relations with people, it has transformed into something else, directly related to oneself. One can say that the effect of "renewal" has become the effect of "cleansing" in thoughts, incentives and reality from a negative side. Emotional "reset" is necessary for the modern Japanese to prevent emotional "outbreak", which can have certain negative consequences.

The word "anime" comes from the Latin word "anima", that means "soul" or "spirit" in Russian. It can be noted that the name and concept of the culture is inseparable from such theory as animism. It has been proposed and further developed by such researchers as G.E. Stahl, E.B. Tylor, R.R. Marett and L. Ya. Sternberg. Taylor was the first who called all studies about the soul by "animism" (Tylor, 1989: 152) and explained the theory and specific rituals contained therein.

Transferring the status of early belief to the concept of Japanese animation, meaning that "the soul is an impersonal inception", it can be assumed that each character has its own spirit and nature. Remarkably, secondary characters, crowd of people where one does not play a role, are depicted as gray, white and flesh colours with rare lines. 
Being in a mass crowd, people miss their Face, and, thus, do not have a thoughtout, creative and rich soul. These phenomena (creation of characters with thoughtful external and internal qualities and, at the same time, a faceless mass existing) can explain what the Japanese consider main anime-characters as inspirited, and if the fans want to make them part of their lives, they make them closer, placing the cartoon images in their room or on notebooks. Turning to the cult of cartoon characters, one can say that in Japanese everyday life it is developed quite well: from the festivals of cosplayers clothed as their favourite characters to their images printed on everyday items. Animations focus people's attention on humanism, moral values; they separate good from evil, allowing new generations to form moral principles; they show a new fascinating world of technical inventions and reveal the veil of the future and the past. The emergence of "anime" has allowed the ideals of Japanese beauty and virtue to be captured in many worlds, stories and characters, emphasizing some of the ideas of Shinto religion spirit.

\section{Conceptological framework}

S.A. Tokarev in his works uses the concept of "religious myth", but does not provide any basic ontological features of this concept. "When a myth is an explanation, reflection or justification of a religious ceremony — "cult myth" — it becomes religious per se" (Tokarev, 1990: 531). I.N. Yablokov assumes that in the modern philosophy of myth one can speak about "syncretic archaic, religious, scientific, political, artistic and literary, everyday and social mythology" (Yablokov I.N., 2004: 91). However, asserting that archaic religious myth and modern religious myth are different from each other, $\mathrm{h}$ does not reveal any essential units of this concept as well. Time and again E. V. Ivanova has highlighted the need to use the concepts of "religious myth" or "religious mythology" in the current religious studies. Under this theory, it is important to remind main characteristics of religious myth. "Religious myth allows simplifying the reality and many contradictions of it down to the basic formula of the struggle between Good and Evil [...] In religious myth, the world is understandable and fully cognized, thereby a sense of harmony with the world is felt [...] Religious myth saves people from a fear of reality, focuses not on today's present, but on future improvement" (Ivanova E.V, 2012: 58). "The structure of religious myth can include fairy tales, eschatological myths, religious fantasy, etc. In the context of our narrative research, let's define that each of the listed elements has particular set of mythemes ("functions" according to V. Ya. Propp) regarded as a strict narrative algorithm" (Ivanova E.V, 2012). Mythemes 
are based on triads, dyads and monads as the basic units of narrative text — this is a texture of religious myth, which is preserved in the modern religious mythology. Also, the way how mythological text is related ritual actions (Ivanova E. V.), both in the past and in the present, have been re-emphasized more than once. Indeed, the essence of ceremony is the language of myth. Any religion sets the ideals of behaviour, and myth emotionally and clearly explains them and tells the need to follow them. Also, the studies on religious mythology have repeatedly noted the interest of the modern mass culture in images of infernal characters and their attractiveness gained from the ethical values inversion and narrative ethical and aesthetic rethinking has been emphasized.

Problem statement. Regarding the analysis of comprehension of "good" and "evil" categories in the modern culture, one can note and state their relativity. Depending on the situation, this or that action can be explained by people, as well as by artistic and mythical characters (heroes) as "evil" or "good". This explanation can be applied both to different and to same actions. In other words, we are looking at ethical pluralism as a special case of global pluralism, or inversion of the basic ethical categories. One can make it clear that such universal categories of "good" and "evil" are filed as a history, being replaced by "situational categories" of good and evil (Ivanova E.V, Vostretsov E.U. 2015:1534). Therefore, not only "positive" characters, but also those belonging to the infernal world, are becoming popular in the mass media space. The world of infernal heroes is being filled with the same existential problems as of the "positive" ones: they are not strangers to love, search for meaning, self-improvement and desire to change for the better. Moreover, the modern infernal cultural heroes of American and English TV series for the youth are experiencing many psychological problems, especially in the search for "how to become human again", how to live in harmony with other people and family values. Is this the same happening in the world of anime? What Western European and American aberrations can be traced in this phenomenon of Japanese animation? And what remains traditional and peculiar to a "purely Japanese" mentality?

\section{Methodology}

In the space of modern culture of media discourse, religious mythology can manifest itself in various ways, for example, through serial chronotopes, cinematography (in the researches by E. V. Ivanova), so, in this case, we are interested in the ones seen in the Japanese "anime". Therefore, this research has been based on the study of Shinto by the orientalists (Nakorchevsky A.A., Ivanov B.A., Ermakova L.M.), as well as on the 
works on the modern Japanese anime (Katasonova E.L., Mikhailova Yu.D.) and on the methods used in visual sociology.

For our research, it becomes important to note the attractiveness of infernal heroes in the modern media space of Japan, which, in our observation, manifests aberration of the Western culture to the Eastern one. At the same time, the researchers address Oriental motifs being different in the Western cultural contexts (Ivanova E.V Racichskykh D. O., 2018: 166), yet the opposite influence cannot be ignored, especially if these are different mass-media manifestations. The reasons for such attractiveness of infernal heroes lie, as we have mentioned above, in ethical reflections of the good and evil inversion.

\section{Discussions}

Traditional beliefs of the Japanese are characterized by the recognition of "kami" in their everyday life. The researchers of Japanese culture describe the reasons for these beliefs: "The Japanese treated the phenomena of nature and human beings as the force full of life: everything was inspirited with a special kind of life. Such vital capacity, differing from the mundanity by colour, form, etc., was perceived as "maximum" ... It was defined by the word "kami", the main meaning of which is "highest", "peak" or "maximum". Everything that has extraordinary power, or beauty, or form, was the subject of worship - or, more precisely, called "kami" and the list of "kami" had no limits: an awe mountain, bizarre rock, shooting mountain stream, centuryold tree ..." (Mifologii drevnego mira, 1977: 406). The orientalists, thus, understand "kami" as "divine entities" or "spiritual entities" (Nakorchevsky, 2003: 63-146), which have their own history, appearance and functions and can be both good and evil; they can help, protect and lead astray. Kami are divided into some categories that help distinguish between the spirits' functions and origin. Thus, A. A. Nakorchevsky identifies mythological, historical, foreign folk kami. B.A. Ivanov suggests other groups: the spirits of nature, odd deified personalities, deads and abilities. However, in the structures proposed by A. A. Nakorchevsky and B.A. Ivanov are difficult to say where "animated films kami" can be attributed to, since the Shintoists believe that the whole nature has a soul, and, therefore, it is treated as alive. The boundaries between animated and inanimated nature are blurred. If you focus on artificial origin of "animated kami", as the monads of religious mythology, then it is worth referring to the product of people's creative activity, to "mythological kami". However, it is necessary to take into account the increasing use of "anime" heroes in everyday life, 
the desire of the Shintoists to make their image a part of themselves, of their family and their world. The fact of the mass production and distribution of the "anime" culture in the mentality of modern Japanese is of no little interest as well. Also among the fans of "anime", or "otaku", as they call themselves, there is a phenomenon of creating a "temple at home" of character figures, manga, video files, posters, and other items. Some fans make characters a part of their life, family, creating their own comfortable virtual world for themselves. Therefore, the characters of "anime", like many other cultural heroes of religious mythology, can be attributed not only to mythological, but also to folk "kami".

Another version of the classification allows you to select a new category of "kami", without attributing animated characters to the mythological or folk ones, i. e. animation. Basing on its existence and definition, further conclusions are made. One should consider the animation kami category as an area in the current spirit systems that unites all the categories, since different ideas and already existing images in mythology, history, other cultures and people can influence characters' creation. So, for example, the character "Magi: The Labyrinth of Magic" (Koji Masunari, 2014). Sinbad is a Chinese sailor Sanbao. The mythological kami can include God of war Yato from the animated series "Noragami" ("Stray God") (Koutaro Tamura, 2014). The borrowed category can be represented through superheroes, vampires, werewolves and witches, but, despite the fact that the characters are borrowed, by recreation of their image they become a part of the Japanese culture and acquire peculiarities of a typical Japanese mentality, lining up with certain Shinto beliefs. For example, the heroes of "Shiki" ("The Dead") are buried disregarding the ceremony, so they turn into the forest vampires. A good example of borrowings is a protagonist of "One punch-man" (Shingo Natsume, 2015): the most powerful young man who copes with any enemy spirit at one blow. The category of animated folk "kami" is very popular with the directors of animated series or films. For example, the main character of "Tasogare Otome $x$ Amnesia" is the yūrei of the young girl. Yūrei is a soul of a dead person, which does not realize that she is also dead, and therefore appears at the place of death. Infernal religious mythology in "anime" can also be expressed by mythological "kami", as they are associated with conventional legends and stories, and folk "kami", since any person after death can become a ghost demon. L.M. Ermakova notes: "Oka Masao, a Japanese researcher, has discovered five types of spirits or deities and phenomena empowered with extraordinary traits: 1) Mot - that is common to a man or natural objects, 2) Toma - the most general concept of the soul, which is attributed not only 
to humans and objects, but also has much wider meaning, 3) Marebito - the spirit of an ancestor or a ghost; both come from afar. 4) Kami - a concept closest to the Russian word "deities", 5) stellar bodies and elements - the sun, moon, stars, winds, thunderstorms, etc" (Yermakova, 2010: 59). In this case, "kami" are understood merely as entities gifted with supernatural abilities and character. Consequently, the term "kami" can be used to name the demons, but not ghosts with human nature and origin, while popular evil ghosts who for various reasons have supernatural powers, are called "marebito".

L.M. Yermakova compiles a long list of spirits (Yermakova, 2010: 65-100), which are divided according to their roles. "Araburu kami — in the mythological frame — as a violent and rude deity" is applied to otherworldly forces that plague fire and calamities. Gongen - an image of the Buddha, who takes the form of kami to protect people. Dosojin are deities that inhabit the intersections, roads and borders. Ikushima are deities engaged in protection and servicing for certain territories belonging to the Emperor. Inari - homemade spirits, assistants in agriculture. Kojin — homemade spirits guarding the family, kitchen and hearth, although, their external image is terrifying: eight heads, eight or six hands, dressed in aristocratic attire and headwear. Marebito is mentioned by L.M. Yermakova exclusively as a stranger who comes in a settlement or community. Ryjin are the gods of storm and thunder. Suijin represent all water spirits. Thianshin are ancestral spirits". In that system of spirits, "arabur", "kami”, "dosojin", "kojin", "suijin", "tiensin" may possess the qualities that are dangerous for people. All "infernal heroes" are called "obake". Obake category can also include yōkai spirits that have been borrowed by the Japanese from China and mean certain energy. All Japanese yōkai can be divided into five large groups (following the classification of K. Yanagita, an outstanding ethnographer and expert on the Japanese folk culture): those who live in the mountains; in water reservoirs (sea, river, pond); on the road sides; in houses; yōkai who, appearing under very specific circumstances and in strictly defined situations, are not so much bound to the landscape. For example, one can consider a baku as yōkai (creatures eating bad dreams), burburu (spirit of fear, weakness, cowardice), oni (giants), reiki (ghosts who have not found peace after death), tsukumokami (spirits of old things), and etc.

Analysing the types of "spirit-demons" in the conception of Shinto and Japanese Buddhists, one can identify the following common features: the spirit has will; has its own everyday interests; the appearance of the demon may differ from the human by any animal component, as well as it can also be completely copied; it appears only in 
darkness, or in a place that closed from the light and offers a test on which the fate of the person may depend; the demon can be peeved at people because of little attention to itself (for example, the spirits of lost things); abilities aimed at concentration of their energy on the object.

Another demon that has not been mentioned in the anime "Nurarihyon's Grandson", despite the fact that in the legends about a hundred demons parade and it has been depicted by Andrew Kawasaki, is baku. This is a Chinese chimera with the body of the bear, the elephant's trunk, with the eyes of the rhinoceros, with the cow's tail, the tiger's paws and spotted skin. It eats good dreams, but can also send nightmares. It is believed that the baku possesses the technique of hypnosis. The prototype of this demon has been used by the developers of Pokemon series (Kunihiko Yuyama, 1998). Drowzee, a character, differs from the original only in external qualities and unwillingness to make people mad, sending terrible dreams on them. It is able to hypnotize enemies, thus putting them to sleep, and then eat their dreams. When Drowzee eats a bad dream, it starts to stir up. If you sleep next to this pokemon, then you can see one of the dreams that it has eaten.

There are examples of various animated series, where the authors try to simulate the demons' leisure time by fitting them into the modern world. For example, the anime with historical information describes the everyday life of spirits. "Sengoku Wildlife Caricatures" (Kumamoto Hiromu, 2017) depict demons, dynasty guardian spirits, forest spirits and protectors as ordinary bums, following the age-old traditions. In the anime "Fairy Tail" (Shinji Ishihira, 2003) has a whole system of relations between the spirits and mythical characters, which is similar to the ones in people's society. The authors of "interviews with Monster Girls" also put forward the idea of connecting and dissolving a mythical society in the human one, where the spirits are not treated as dangerous or special.

There are also such screened ideas, in which the attention is focused on the interest of demons in the people's lifestyle. For example, the main character of "Blood Lad" has always dreamed of meeting a man. The prototype of his image is a synthesis of the vampire through the European and Japanese vision. He does not have animal appearance, like the spirits, exhausting the power and life of people, but either does not feed merely on blood; it carries light, unlike the vampires, which can be found in the European film screenings.

The influence of Europe and America on the Japanese animation in the process of aberration has been mainly expressed in the emergence of the idea of absolute evil 
concentrated in one character - Satan. However, in the plots of "anime" this infernal image has been developed differently than in the Bible. For example, a minor character and a ruler of the underworld in "Blue Exorcist" TV series (Tensai Okamura, 2011) has rather biological interest in people, than the derogatory one. He falls in love with a mortal girl, studies the world in which he has never been before; he decides to have children with a man, and has tender feelings for the world and its creatures. His goal is not to destruct the world, or to throw temptation to people, though, when the monks decide to kill a pregnant girl and her new-born children, his anger, rage and hate are destructs everything around. Such a reaction is caused by the feelings, and not by the intention to kill, which can be judged later on by the mad main character having gone mad. The idea of the absolute evil appearance, as interpreted by the authors, should have a cause. Therefore, this infernal cultural hero wanted to avenge his beloved, therefore his half-people children can use the force and blue flame only when there is an urgent need.

The appearance of absolute evil hero is represented only by the blue fire, that leads to a conclusion, that evil has no form, however, it has its own attributes. There are some changes in the bodies of those people in whom the evil spirit is infused: their teeth become sharp, the nails are long and strong, the tips of the ears are enlarged and sharpened.

This character also possesses positive features in "The Devil is a Part-Timer!" TV series (Naoto Hosoda, 2013). Mao, that is the name of the main character, is going to conquer the whole world, but is defeated by the hero Emilia and escapes to a parallel world in which he finds himself in the modern Tokyo. The reasons for the desire to take over the world are not clear, but, judging from the storyline, one can determine these reasons as disobedience of the demons to Satan, representing the elite in the parallel world. However, the king of darkness, who arrives on Earth after this failure, leaves all the evil intentions, and even finds a job. Emotionally, he becomes an ordinary person; he is not cunning and he does not lie, but even falls in love with a girl, taking the refugee generals into their ranks. It is also noteworthy that Satan and Lucifer in this anime are two different characters while in the Bible they are referred to as synonyms. Satan's appearance in this interpretation is anthropomorphic, but when using the power, it is again copied from the images of ancient Greek satyrs.

The name Beelzebub is also considered synonymous with the devil, Satan, Lucifer, and etc., but there are some authors who have suggested that this demonic creation can 
be a child of Satan, having a destructive power. The authors of "Beelzebub" (Nabuhiro Tokamoto, 2012) have made the baby capricious, but with a great physical strength, qualities of a teaser and egoist, which is not the case with the biblical Satan.

In the Bible, Satan is a male, but the authors of "Archenemy and Hero" have decided to interpret the image in their own way. This is due to the fact that the purpose of Satan on Earth was to create the conditions to develop technology, agriculture and trade, improving the quality of life. Traditionally, in ancient beliefs, a woman was engaged in farming, since by her nature she had a reproductive function. The Shintoists also believe in the existence of patrons of crops, rivers, irrigation, and etc. Mostly these spirits are female. Thus, according to the plot concept, the Devil began to perform the functions that Satan was supposed to. One would think, why to use the image of Satan, if you could put in his place one of the fertility spirits? The authors have regarded the fact that the biblical Satan could give and take power over the nations, he could control them by using cunning, intelligence, and spiritual human weaknesses. The Archenemy, in her turn, drives the progress through agricultural reforms. The appearance of Satan is human, but the presence of large black horns explains the same thing as in the previous interpretations.

\section{Conclusion}

It is possible to consider the presence of demons in anime as a Japanese rethinking of the prototype image, its adaptation to the society, and as some development of mythological plots. Buddhism and Christianity undoubtedly influence the images of animated characters, but the ability of the Japanese mentality to create scary stories in which people can believe through generations will always be more significant. In this regard, there is the problem of multi-valued definition of the demon image in Japanese animation. A distinctive feature of all the studied demonic cartoon characters is the absence of unreasonable aggression, which allows to highlight the focus of Japanese animation on the moral education of the viewer; the demons in anime can set an example for people; their history, kindness, friendliness encourage the younger generation to create a society without war and with favourable conditions for individual socialization. The process of aberration in the Japanese anime occurs only in parts; the infernal characters and heroes are filled with only externally defined European narrations, and have only an outward, superficial resemblance to their prototypes in European and American religious mythology of mass culture. 


\section{References}

Ivanova, E.V. (2012). Religious Fantasy as Element of Contemporary Religious Mythology. In: J. Sib. Fed. Univ. Humanit. soc. sci., 5(1), 56-62.

Ivanova, E.V., Vostretsov, E. Yu. (2015). Contemporary Religious Fantasy Inversion of Etical Categories. In: J. Sib. Fed. Univ. Humanit. soc. sci., 8(8), 1534-1540.

Ivanova, E.V., Rachitskih, D.O. (2018). Sravnitel'nyj analiz filosofskih shkol indijskogo, kitajskogo i yaponskogo buddizma v svete aberracii orientalistskih motivov religioznoj filosofii postmoderna [Comparative analysis of the philosophical schools of Indian, Chinese and Japanese Buddhism in the light of the aberration of Orientalist motives of the religious philosophy of the postmodern]. In Izvestia. Ural Federal University Journal. Series 3. Social Sciences, 13(2), 165-174.

Mifologii drevnego mira [Mythologies of the Ancient World] (1977). Moscow, Nauka, 456 p.

Kumamoto Hiromu, Sumido Takahasi (2017). In: Sengoku Wildlife Caricatures. Tokyo, Ilca.

Kunihiko Yuyama, Norihiko Sudo, Masamitsu Hidaka (1998). In: Pokemon. Tokyo, OLM.

Masunari Koji (2014). Magi: The Labyrinth of Magic. Tokyo, A-1 Pictures.

Masurao Takahasi (2013). Archenemy and Hero. Tokyo, Arms.

Nabuhiro Takamoto (2012). Beelzebub. Tokyo, Studio Pierrot.

Nakorchevsky, A.A. (2003). Yaponskie bozhestva kami [Kami: Japanese Divines]. In: Yaponiya. Sinto [Japan. Shinto]. Saint-Petersburg.

Naoto Hosoda (2013). The Devil is a Part-Timer! Tokyo, White Fox.

Shin Oonuma (2012). Tasogare Otome x Amnesia. Tokyo, Silver Link.

Shingo Natsume (2015). One Punch-Man. Tokyo, Madhouse.

Shinji Ishihira (2009). Fairy Tail. Tokyo, A — 1 Pictures, Satelight.

Tamura Koutarou (2014). Stray God. Tokyo, Bones.

Tensai Okamura (2011). Blue Exorcist. Tokyo, A - 1 Pictures.

Tetsuro Amino (2010). Shiki. Tokyo, Daume.

Tokarev, S.A. (1990). Rannie formi religii [Early Forms of Religion]. Moscow.

Tylor, E.B. (1989). Pervobytnaya kultura [Primitive Culture]. Moscow.

Yermakova, L.M. (2010). Mify i bozhestva [Myths and Deities]. In: Bogi, svyatilischa, obryady Yaponii. Entsiklopediya Sinto [Japanese Gods, Temples and Ceremonies. Shinto Encyclopedia]. Moscow, Publishing Center of Russian State University for the Humanities. 
Yablokov I.N. (2004). Religiovedeniye [Religion Studies]. Moscow: Gardariki, 2004. 317 p.

\title{
Религиозная мифология: проблема аберрации инфернальных героев в японском «аниме»
}

\author{
Р.А. Бурханов ${ }^{\text {, Е. В. Иванова }}{ }^{\boldsymbol{\sigma}}$, А.Д. Колпакова ${ }^{\boldsymbol{\sigma}}$ \\ ${ }^{a}$ Сургутский государственный университет \\ Россия, 628403, Ханть-Мансийский автономный округ, \\ Сургут, пр. Ленина, 1 \\ ${ }^{6}$ Уральский федеральный университет \\ им. первого Президента России Б. Н. Ельцина \\ Россия, 620083, Екатеринбург, пр. Ленина, 51
}

Статья продолжает исследование авторов, посвященное особенностям проявления современной инфернальной религиозной мифологии в пространстве масс-медийности. Интерес обращен на анализ локусов религиозной мифологии с точки зрения аберрации героев западной культуры на восточную, японскую. Тем самым расширяется нарративная область применения авторского понятия "религиозная мифология». Взаимодействие массовой культуры и религии в рамках одного исследования встречается все чаще, однако синтаксис синтоизма и «аниме» - редко встречающаяся и актуальная тема. В данной статье авторы поставили перед собой задачу - рассмотреть и проанализировать влияние синтоизма, христианства, буддизма и американской культуры на интерпретацию инфернальных культурных героев (персонажей) в медиадискурсе японской анимации, разработанных в ходе создания мультипликационных фильмов и сериалов.

Ключевые слова: миф, религия, религиозная мифология, массовая культура, культурньй герой, инфернальный культурный герой, японское аниме, японская культура.

Научная специиальность: 09.00.00 - философские науки. 